\title{
Mechanical tillage of degraded mining areas at Jamari National Forest (Amazonian Forest, Rondônia - BR)
}

\author{
A. Í. Ribeiro ${ }^{1}$, A. J. S. Maciel ${ }^{3}$, R. M. Longo ${ }^{2}$, W. J. Melo ${ }^{1}$ \\ \& R. W. Lourenço ${ }^{1}$ \\ ${ }^{1}$ University State of São Paulo, UNESP, Brazil \\ ${ }^{2}$ Pontifícia Universidade Católica, PUC-Campinas, Brazil \\ ${ }^{3}$ State University of Campinas, UNICAMP, Brazil
}

\begin{abstract}
According to the environmental legislation enforced in Brazil and the process of marketing globalization, the commitment of nation to the preservation of the environment is intensified. By reason of nature's negative responses to its intensive use, an awareness then appears from enterprises and agencies about how the anthropic action over the environment needs to be minimized, becoming a challenge: development and sustainability. In this context, the present work made use of the mechanical tillage of the soil as a technique to apply, in a large scale, the strategies and methods to recover mined areas that were researched and developed experimentally by researchers on a theme project about the recovering of degraded areas. This work was conducted in the Amazon ecosystem, inside the Jamari National Forest - Rondônia (FLONA do Jamari), in deactivated cassiterite mines. The objectives of this work were to:

- Develop a computational program capable of managing a database and assist in the selection of machines and preparation methods to execute the operations of topographical reconstitution and tillage of surfaces in areas degraded by the mineral exploitation of cassiterite.

- Use the program that was developed in the planning of costs and operational development, for the operations required in the strategies for recovering the areas.

- Analyze the vegetable productivity in the mobilized areas and the quality of the superficial mobilization, making use of indicators and tillage methods.
\end{abstract}


- Evaluate, through biological indicators, the efficiency of the recovery strategies and techniques that were mechanized and applied on the location.

The results showed that the developed computational program (SGMAD) served the methodological purposes (the analysis of costs and operational capacity) established for the planning and the selection of the tillage machines and methods in the areas of mineral exploitation of cassiterite. The applied methods and quality of the superficial mobilization were significant to the development of leguminous plants in the areas. The use of biological indicators (microbial biomass and enzymatic activity) in the evaluation of the adopted techniques and strategies revealed that the planting of leguminous plants and their posterior incorporation have been promoting gradually positive alterations in some of the analyzed soil/substract parameters.

Keywords: degraded area, recovery, Amazon forest, mining, tillage, mechanization, machines, costs, soils.

\section{Introduction}

Mining or mineral exploitation constitutes an indispensable activity in modern society, given the importance that mineral assets and their derived products have acquired in the world's economy. However, the use of a nation's natural resources implies directly the manipulation of natural environments of the terrestrial surface. In this scenario, estimated indicate that mining contributes with one percent $(1 \%)$ of the degradation of the planet's soils. Even if it seems to be a small value, this percentage denotes a high intensity of degradation. This degradation of the environment causes great modifications to the system, having a strong effect on the landscape, because it requires the removal of the vegetation, of the soil and of the rocks that are above the mineral deposits.

In this context, given the current environmental legislation and the process of marketological globalization, the commitment of the nations regarding the environmental preservation is intensified. It appears, therefore, on account of nature's negative responses to its intensive use, an awareness, by enterprises and organizations, that the anthropic action over the environment has to be minimized, becoming a challenge: development and sustainability. In this universe, Brazil is one of the countries which exploits its mineral resources the most in the western world.

Thus, an important component in the exploitation of mineral resources is the rehabilitation and/or recovery of degraded areas generated over the mining process, especially surface mining, which presents great impacts on the soil and the landscape. This recovery constitutes a complex task, once it involves different techniques and strategies. These techniques and strategies depend on the future use of the area. A simplified elucidation of the different actions on a mined area can be observed on Figure 1, adapted from Sanchez [9].

In this insertion, it is possible to note that in each phase, according to the area and the level of degradation, the use of mechanization techniques becomes practically vital. 


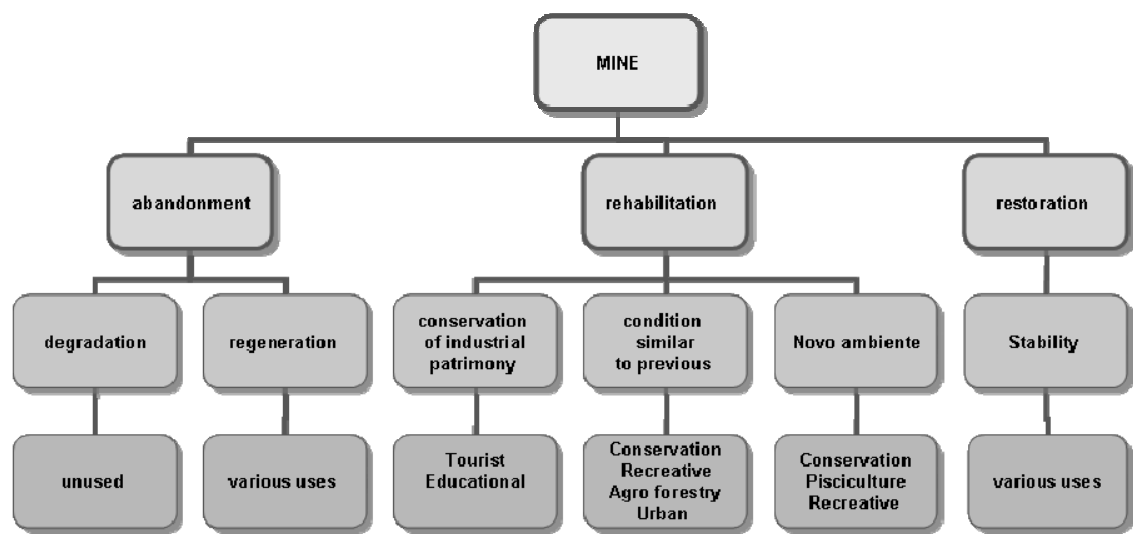

Figure 1: $\quad$ Recovery of areas degraded by mining.

Even being an important factor in the recovery of degraded areas, few publications in the country report the application and the viability of mechanization in the process of revegetation of mined areas. In this sense, given the great variability of machines and equipment existing in the market, studies become necessary for a better adequacy and optimization of the mechanized systems in the recovery of degraded areas.

The present work contemplated part of a theme project, with the purpose of developing a methodology for the recovery of areas degraded by cassiterite (tin ore) exploitation inside the Amazon ecosystem in the Jamari National Forest/RO (FLONA). The National Forests, according to the law that institutes the National System of Conservation Units (Sistema Nacional de Unidades de Conservação), are areas with forest coverage of mainly native species and this system has as a basic objective the multiple, sustainable use of forest resources and scientific research, with emphasis on methods for sustainable exploitation. Thus, the multidisciplinary theme project relied on the participation of many researchers of different areas, resulting in theses, scientific works and works of technical exposure.

In the development of the theme project, initially studies were conducted in a greenhouse, as well as field works, obtaining important results over a small experimental scale. This way, mechanization was used in the preparation of the soil and other operations, starting from the premise that it is possible to apply, in a large scale, the strategies and recovery techniques developed in an experimental scale.

Generally, the mechanization techniques present themselves as a helpful tool in the execution of the recovery strategies, especially in large mined areas. The multidisciplinary character of the theme "mechanization and revegetation" involves different sciences and knowledge bases, being that, normally, the revegetation of an area has as a final goal a quick establishment of the local native vegetation, with as little as possible use of production inputs and surface mobilization, promoting the reintegration of the areas and minimizing the impact of mining activities on the environment. 


\section{Material and methods}

\subsection{Description of the area of study}

The Jamari National Forest (FLONA), administered by the Brazilian Institute of Environment and Renewable Mineral Resources - IBAMA, is located $90 \mathrm{~km}$ from the city of Porto Velho - RO, through the Br-364, heading towards CuiabáMT, being one of the most privileged of the North region, because of its geographical position and access ways (Fig. 2).

LOCALIZAÇÃO DA FLORESTA NACIONAL DE JAMARI
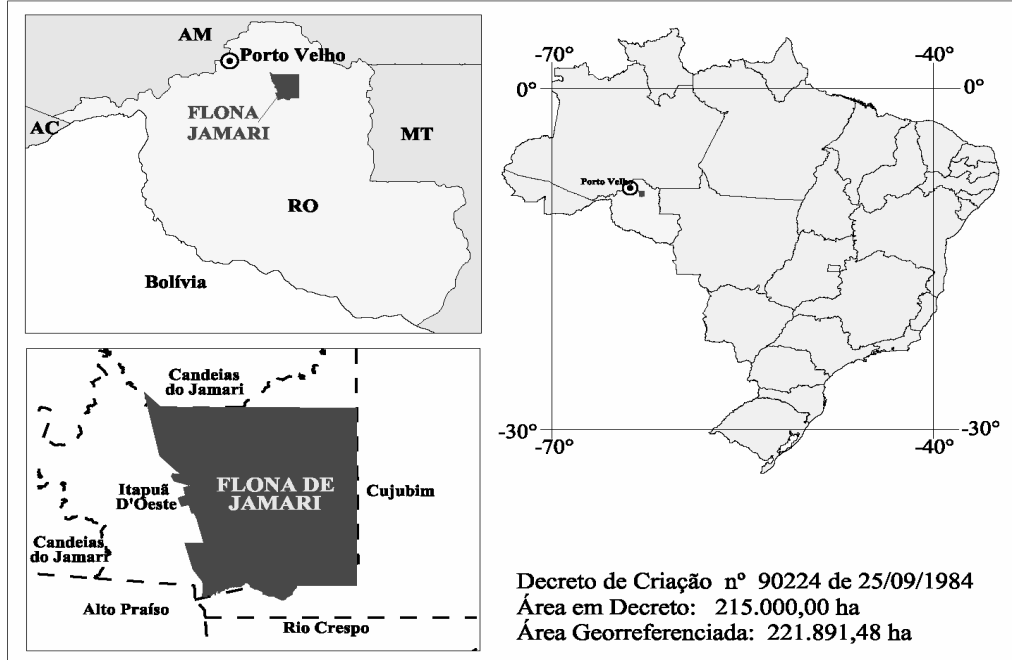

Decreto de Criação $\mathrm{n}^{\circ} 90224$ de 25/09/1984

Área em Decreto: $215.000,00$ ha

Área Georreferenciada: $221.891,48$ ha

Figure 2: $\quad$ Location of the Jamari national forest.

The rate of deforestation in the area is extremely high, especially due to the agricultural and farming projects located in the BR-364 highway's area of influence, to the mineral exploitation activities and to the development of urban centers.

The Jamari National Forest presents an area of approximately 225.000 ha, of which $90 \%$ are covered by Tropical Open Forest, where can be found species of high commercial value for wood exploitation, being also rich in ores (Project RADAM BRASIL [5]).

The soils are predominantly of the class Rhodic Ferralsol and Xanthic Ferralsol, acid, with $\mathrm{pH}$ varying from 3,4 to 5,0. The climate of the region is hot and wet, with average temperatures of $24^{\circ} \mathrm{C}$, presenting an annual precipitation of $2550 \mathrm{~mm}$, having its maximum in the months from December to March. The relative humidity is around 80 to $85 \%$, there being a clearly defined dry season with its most critical period between July and August.

The main areas degraded by mining inside the Jamari National Forest receive the following names: April 14, São Sebastião, Potosi, Serra da Cacimba, Poço B, 
Novo Mundo, Duduca, Serra da Onça. The present work was conducted in the mines: Serra da Onça and April 14.

\subsection{Classification of the substracts and recovery strategies in the experimental areas}

The different activities and processes involved in the cassiterite mining result in substracts with characteristics that originate, mainly, from the type and composition of the matrix rock, from the processes of degradation and from the form and time of exposure of the remaining material. Due to the large variety of situations, it was necessary to classify the material to be recovered, to define the techniques and strategies to be applied and, consequently, the necessary operations.

The considered classification of the substracts for the experimental areas and the different strategies adopted is presented in Table 1.

Table 1: Different substracts and strategies observed in the areas to be recovered.

\begin{tabular}{l|l}
\hline $\begin{array}{l}\text { Substracts } \\
\text { Non-decapped }\end{array}$ & Recovery strategies and techniques \\
\hline Decapped area & $\begin{array}{l}\text { Legumes planting } \\
\text { Organic fertilizing in pits } \\
\text { Chemical fertilizing } \\
\text { Planting of native species }\end{array}$ \\
\hline Slopes and cuts & Planting of grasses \\
\hline Mining floor & $\begin{array}{l}\text { Legumes planting } \\
\text { Chemical fertilizing } \\
\text { Organic fertilizing in pits } \\
\text { Planting of native species }\end{array}$ \\
\hline \multirow{2}{*}{ Tailing areas } & $\begin{array}{l}\text { Use of "topsoil'(recoverage) } \\
\text { Legumes planting } \\
\text { Chemical fertilizing } \\
\text { Organic fertilizing in pits } \\
\text { Planting of native species }\end{array}$ \\
\hline
\end{tabular}

\subsection{Identification of the main operation in the topographical reconstitution and superficial mobilization of degraded areas}

Three large sets of alternatives applied to the recovery of degraded areas were identified, that can be distinguished in terms of the predominance of the field of study that bases each of them: revegetation, geotechnologies and remediation. These alternatives have as a goal the biological, physical and chemical stability of the environment. In this context, the option was made for the local revegetation, considering that the areas are found in a National Forest. The 
operations of topographical reconstitution and preparation of the surfaces were considered basic and from them originated the sub-operations, as Table 2 shows.

Table 2: $\quad$ Main operations of topographical reconstitution and preparation of surfaces in degraded areas.

\begin{tabular}{|c|c|}
\hline Topographical reconstitution & Surface preparation \\
\hline $\begin{array}{l}\text { Smoothing: it consists in smoothing } \\
\text { parts of the very irregular terrain that } \\
\text { may compromise the preparation of the } \\
\text { surface for planting or revegetation }\end{array}$ & $\begin{array}{l}\text { Plowing: operation of cutting, } \\
\text { raising, inversion and pre- } \\
\text { disaggregation of the of the top of } \\
\text { the soil/substract }\end{array}$ \\
\hline $\begin{array}{l}\text { Terracing: Construction of structures to } \\
\text { retain the superficial pluvial flow in the } \\
\text { area through terraces }\end{array}$ & $\begin{array}{l}\text { Harrowing: operation of breaking } \\
\text { the clods and leveling the top of the } \\
\text { soil/substract }\end{array}$ \\
\hline $\begin{array}{l}\text { Resloping: smoothing of abrupt cuts } \\
\text { aiming planting or revegetation }\end{array}$ & $\begin{array}{l}\text { Chiseling: rupture of compacted } \\
\text { sub-superficial layers of the } \\
\text { soil/substract }\end{array}$ \\
\hline $\begin{array}{l}\text { Removal: removal of the material of } \\
\text { the soil/substract for later use in } \\
\text { planting or revegetation }\end{array}$ & $\begin{array}{l}\text { Subsoiling: practice of rupture of } \\
\text { layers compacted in a depth above } \\
40 \mathrm{~cm} \text {. }\end{array}$ \\
\hline $\begin{array}{l}\text { Transportation: translocation of the } \\
\text { substract to considerable distance }\end{array}$ & $\begin{array}{l}\text { Rotovation: operation of } \\
\text { soil/substract preparation making } \\
\text { use of rotating hoes. }\end{array}$ \\
\hline $\begin{array}{l}\text { Compactation: it consists in } \\
\text { compacting disaggregated substracts so } \\
\text { as to improve the stability for later } \\
\text { planting }\end{array}$ & $\begin{array}{l}\text { Furrowing: practice of making } \\
\text { furrows in the soil/substract }\end{array}$ \\
\hline $\begin{array}{l}\text { Trenching: opening of canals so as to } \\
\text { help in the control of local erosion }\end{array}$ & $\begin{array}{l}\text { Pitting: perfuration of cavities along } \\
\text { the surface of the soil/substract }\end{array}$ \\
\hline $\begin{array}{l}\text { Leveling: promote the systematization } \\
\text { of the area through a pre-established } \\
\text { level }\end{array}$ & $\begin{array}{l}\text { Capping: covering a certain surface } \\
\text { with some substract of interest with } \\
\text { the objective of planting }\end{array}$ \\
\hline
\end{tabular}

\section{Results and discussion}

\subsection{Development and usage of the software SGMAD}

Software capable of helping in the selection of machinery and implements in the re-vegetation of areas mined by cassiterite exploitation was developed. The system was developed for Windows environments, having Object Pascal of the program "Borland Delphi6" as programming language. The basic operations considered were the topographical reconstitution and the preparation of the surfaces. This algorithm is formed by: a database, routines with production analysis and average cost of operations. 
The main selection parameter was the type of operation to be executed. The production routines and the average cost of the machinery were used as support to the decision in the choice of machinery. The result of the analysis was a printed report, with the different options for mechanization to develop the set of operations in the field. Table 3 presents the final results of the cost analysis in the areas worked for topographical reconstitution. The operation of smoothing of the surface was the one which presented the higher total cost, being the resloping operation the highest operational cost per $\mathrm{m}^{3}$, followed by the transportation of soils/substracts which presented the highest hourly cost.

Table 3: Machines and manufacturers [topographical reconstitution].

\begin{tabular}{|c|c|c|c|c|c|c|}
\hline Tractor & Equip. & Model & Oper. & $\begin{array}{l}\text { Op Cost. } \\
\text { US/horas }\end{array}$ & $\begin{array}{c}\text { Op. Cost } \\
U S / m^{3} \\
\end{array}$ & $\begin{array}{c}\text { Total } \\
\text { Cost.US }\end{array}$ \\
\hline D6D & $\begin{array}{l}\text { Straight } \\
\text { blade } \\
\text { Tiltdozer }\end{array}$ & $6 \mathrm{~S}$ reta Cat & Smoothing & 77,79 & 0,90 & 5400,00 \\
\hline \multicolumn{2}{|c|}{ Cat Trencher } & 225 Retro & Resloping & 58,28 & 1,79 & 1969,00 \\
\hline \multicolumn{2}{|c|}{ Cat Trencher } & 225 Retro & Removal & 58,28 & 1,44 & 3168,00 \\
\hline D6D & $\begin{array}{l}\text { Straight } \\
\text { blade } \\
\text { Tiltdozer }\end{array}$ & $6 \mathrm{~S}$ reta $\mathrm{Cat}$ & Terracing & 77,79 & 0,22 & 880,00 \\
\hline Mercedez & Truck & 1935 & Transportation & 106,71 & 1,71 & 3420,00 \\
\hline
\end{tabular}

Table 4 presents the final results of the cost analysis in the areas worked for the superficial mobilization of the areas. The operation of surface pitting was the one which presented the highest total cost. This factor is associated to the low operational capacity of the soil drill. The operation of soils/substract capping presented the highest cost per area, a factor also associated to the low operational capacity. This operation finalizes the strategy of soil coating, and it is never executed in isolation, preceding the operations of storage, removal and transportation.

Table 4: Machines, models and performance estimated [superficial mobilization].

\begin{tabular}{c|cccccc}
\hline Tractor & Equipment & Model & Operation & $\begin{array}{c}\text { Op. Cost } \\
\text { U\$/horas }\end{array}$ & $\begin{array}{c}\text { Op. Cost } \\
\text { US/ha }\end{array}$ & $\begin{array}{c}\text { Total } \\
\text { Cost.US }\end{array}$ \\
\hline D6D & Ripper & N $^{0}$ 6 Paral. Cat & Chiselling & 77,79 & 204,71 & 1432,97 \\
Valmet 985 & Harrow & "GA-14X26" & Harrowing & 43,13 & 95,84 & 1198,00 \\
Valmet 985 & Drill & PS Tatu & Pitting & 42,02 & 420,20 & 3361,60 \\
Case Loader & & W200 & Capping & 51,85 & 864,20 & 2160,50 \\
\hline & \multicolumn{7}{c}{} \\
\hline
\end{tabular}

\subsection{Evaluation of the superficial preparation in the degraded areas}

The following step was used to analyze the quantity and the influence of the soil mobilization in the vegetable growth of legumes in the degraded. 
With that purpose, initially, soil samples were collected so as to characterize the areas to be worked (physical and chemical). After that, analyses of special variability were conducted, in the parameter soil resistance to penetration, before the preparation of the terrains. After the areas were prepared, the mobilization and the disaggregation of the substracts were evaluated as quality parameters, and afterwards the areas planted with legumes. Under these conditions, an evaluation was conducted on the vegetable growth of the legumes, as well as analysis of some soil properties, especially the biological ones, for those are the ones which provide the most prominent answers when the interest is the analysis of sustainability and of the techniques and strategies adopted.

\subsection{Evaluation of the mining floor areas after the superficial mobilization}

The penetrography before and after the subsoiling in the experimental area can be observed in Fig. 3. It is possible to note that there existed a compacted layer similar to those found in agricultural soils under intense handling; however, this one suffered a rupture with the subsoiling.
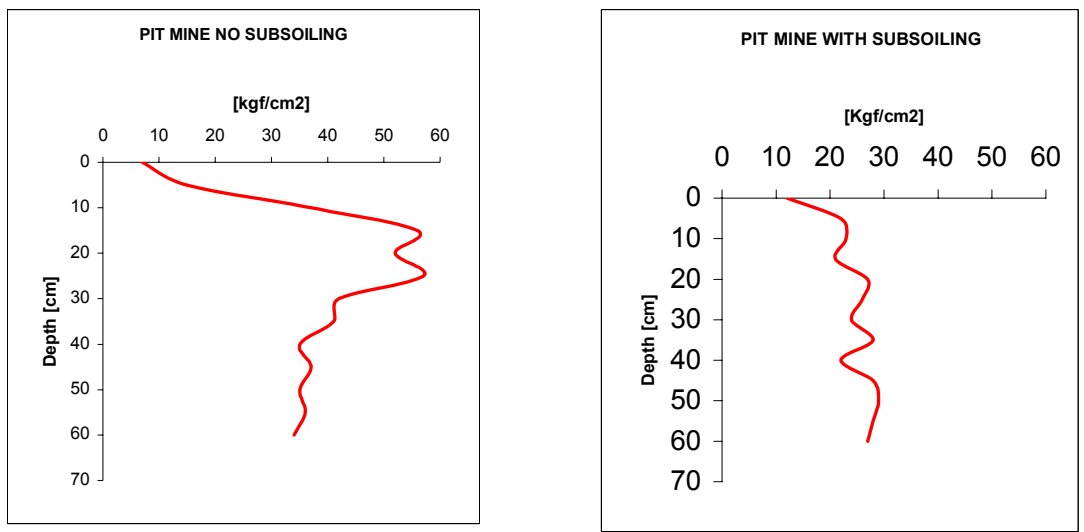

Figure 3: Mechanical resistance to penetration before and after the subsoiling.

A similar operation was executed in the recovery of gravel lands in the Brasília National Park by Leite et al. [3], in which the authors concluded that only the rupture of the compacted layer was not enough to maintain the local vegetation. The profile mobilization of the mining floor area can be observed in Figure 4. 


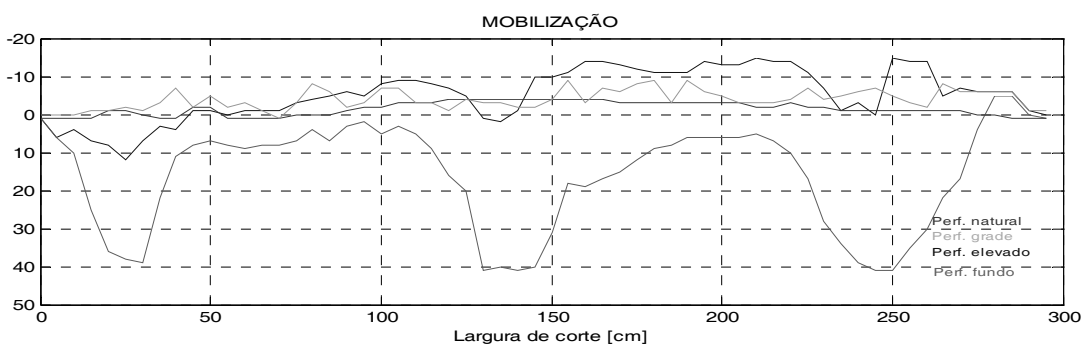

Figure 4: $\quad$ Mobilized mining floor areas.

This type of analysis is usually frequent in the evaluation of machines in soil preparation, where a larger mobilization with a lower energy requirement is sought (Ribeiro [8]). It is possible to observe, in Table 5, that the specific power presents values compatible with agricultural operations cited by Ralisch [6].

Given the spacing of the poles, and due to the operation execution, an irregular surface was generated, being possible to note a large thickness of the furrows walls which suffered rupture only in the region of action of the poles. Depending on the recovery strategy adopted, it is necessary to make use of a crossed subsoiling, harrow work or, according to Camargo and Alleaoni [1], the implementation of quick forms to place organic matter in the soil/substract, as, for instance, the planting of legumes and the use of organic fertilizers. In this work, the choice was made for plowing with the use of a harrow, with the objective of improvement of roughness, leveling and higher disaggregation of the surface. These results can be observed in Table 5 .

Table 5: $\quad$ Parameters of mobilization and energy requirement.

\begin{tabular}{l|cccccc}
\hline \multirow{2}{*}{ Operations } & $\begin{array}{c}\text { Mobilized } \\
\text { Area } \\
{\left[\mathbf{c m}^{2}\right]}\end{array}$ & $\begin{array}{c}\text { Elevation } \\
\text { Area } \\
{\left[\mathbf{c m}^{2}\right]}\end{array}$ & $\begin{array}{c}\text { Empol. } \\
{[\%]}\end{array}$ & $\begin{array}{c}\text { Traction } \\
\text { force } \\
{[\mathbf{k g}]}\end{array}$ & $\begin{array}{c}\text { Roughness } \\
\text { index } \\
{[\mathbf{m m}]}\end{array}$ & $\begin{array}{c}\text { GMD } \\
{[\mathbf{m m}]}\end{array}$ \\
\hline Ripper & 6340 & 1128 & 18 & 3850 & 9,2 & 24,8 \\
$\begin{array}{l}\text { Ripper+ } \\
\text { harrow }\end{array}$ & 6340 & 657 & 10 & 263 & 3,4 & 6,9 \\
\hline & & & & & & \\
\hline
\end{tabular}

\subsection{Evaluation of the legumes growth in the mobilized areas of tailing and mining floor}

Throughout the development of this work, it became relevant to discuss the importance and the relation of the surface preparation in the vegetable development, since when an area is prepared, it is necessary to have a clear objective. Analyzing the relation of the vegetable growth of arborical species would become difficult, once their growth usually occurs in a rather slow form.

Thus, we opted for the analysis of the growth of legumes, being the studied variables the amount of dry and green matter per $\mathrm{m}^{2}$. Tables 6 and 7 present the results of the amount of dry and green matter $(\mathrm{g})$ produced per $\mathrm{m}^{2}$ (cocktail) in 
tailing areas. It is noticeable on Tables 18 and 19 that the test was significant, i.e., there is a difference between the deviations. These results show the importance of mobilizing the tailing, considering that the main objective of preparing the soil/substract was to provide favorable conditions to the germination of seeds and to the growth of roots, promoting an adequate environment to the vegetable species (Kepner et al. [2]). The work did not take into consideration the variables relating to the soil and the plant that promoted the differences in the amount of dry and green matter produced. Nevertheless, some local visual observations can be mentioned. A great part of the tailing areas is sandy and has a light mechanical resistance on the surface (sealing). This sealing in a period of high solar incidence permitted a warming around $40^{\circ} \mathrm{C}$ of temperature of the soil/substract surface, making the germination of legumes difficult, according to Longo et al. [4], who describes some relations between soil temperature and germination. Under the occurrence of intense rain, very common in the region, a great quantity of seeds is carried by the rain water, which makes the germination difficult and, consequently, the final stand of cultivation.

Table 6: $\quad$ Green matter $\left[\mathrm{g} / \mathrm{m}^{2}\right]$ produced in tailing areas.

\begin{tabular}{|c|c|c|c|c|}
\hline \multicolumn{5}{|c|}{ Green matter-tailing $\left[\mathrm{g} / \mathrm{m}^{2}\right]$} \\
\hline $\begin{array}{l}\text { Samples } \\
\text { Mobilized } \\
\text { Non-mobilized } \\
\text { Differences }\left[\mathrm{D}_{\mathrm{i}}\right]\end{array}$ & $\begin{array}{c}1 \\
747,20 \\
259,35 \\
\mathbf{4 8 7 , 8 5} \\
\end{array}$ & $\begin{array}{c}2 \\
803,70 \\
177,68 \\
\mathbf{6 2 6 , 0 2} \\
\end{array}$ & $\begin{array}{c}3 \\
594,23 \\
159,05 \\
\mathbf{4 3 5 , 1 8} \\
\end{array}$ & $\begin{array}{c}4 \\
592,02 \\
313,75 \\
\mathbf{2 7 8 , 2 7} \\
\end{array}$ \\
\hline $\begin{array}{l}\text { Average }\left[D_{i}\right]=456,83 \\
\text { Standard deviation }\left[D_{i}\right]=143,59\end{array}$ & $\begin{array}{l}t_{\mathrm{cal}}=6,359 \\
t_{\mathrm{tab}}=\mathbf{2 , 3 5 3}\end{array}$ & & & $\begin{array}{c}\alpha=0,05 \\
\text { Significant }\end{array}$ \\
\hline
\end{tabular}

Table 7: $\quad$ Dry matter $\left[\mathrm{g} / \mathrm{m}^{2}\right]$ produced in tailing areas.

Dry matter-tailing $\left[\mathrm{g} / \mathrm{m}^{2}\right]$

\begin{tabular}{l|cccc}
\hline Samples & 1 & 2 & 3 & 4 \\
Mobilized & 169,38 & 152,93 & 129,01 & 122,85 \\
Non-Mobilized & 81,01 & 67,18 & 46,08 & 44,35 \\
Differences $\left[D_{\mathrm{i}}\right]$ & $\mathbf{8 8 , 3 7}$ & $\mathbf{8 5 , 7 5}$ & $\mathbf{8 2 , 2 1}$ & $\mathbf{7 8 , 5 0}$ \\
\hline Average $\left[\mathbf{D}_{\mathbf{i}}\right]=\mathbf{8 3 , 7 1}$ & $\mathbf{t}_{\text {cal }}=\mathbf{3 9 , 0 0 4}$ & & & $\boldsymbol{\alpha}=\mathbf{0 , 0 5}$ \\
Standard deviation $\left[\mathbf{D}_{\mathbf{i}}\right]=\mathbf{4 , 9 0}$ & $\mathbf{t}_{\text {tab }}=\mathbf{2 , 3 5 3}$ & & & Significant \\
\hline
\end{tabular}

\subsection{Microbial biomass, dehydrogenase activity and nutrients cycling after the incorporation of green fertilizers}

These evaluations were conducted as biological parameters to the analysis of the efficiency of the operations and the recovery strategies. The samples were analyzed in the Biogeochemistry Laboratory of UNESP-Jaboticabal. The carbon and nitrogen analysis were accomplished in accordance with the method proposed by Vance et al. [10]. For the BMC, the highest values were found for 
the woodland, mining floor with three years of planting and one year of planting, and those have not presented significant differences amongst one another (Table 8). Reis et al. [7], studying the effect of planting arborical legumes in the recovery of degraded areas under the microbial activity of the soil, observed that the highest BMC values were found for the spontaneous vegetation, followed by acacia, eucalyptus and intercropping, that did not differ amongst one another.

Table 8: Biomass nitrogen and carbon in a soil mined after the planting of legumes.

\begin{tabular}{|c|c|c|}
\hline \multirow[t]{3}{*}{ Treatment } & \multicolumn{2}{|c|}{ Microbial biomass } \\
\hline & $\mathbf{N}_{\text {mic }}$ & $\mathrm{C}_{\text {mic }}$ \\
\hline & $\mu$ g. $\mathrm{kg}^{-1}$ TFSE & mg.kg ${ }^{-1}$ TFSE \\
\hline T1 & $0,12^{\mathrm{A}}$ & $1090,81^{\mathrm{ABC}}$ \\
\hline $\mathrm{T} 2$ & $1,54^{\mathrm{A}}$ & $880,87^{\mathrm{BCD}}$ \\
\hline $\mathrm{T} 3$ & $1,41^{\mathrm{A}}$ & $1344,25^{\mathrm{AB}}$ \\
\hline $\mathrm{T} 4$ & $1,33^{\mathrm{A}}$ & $466,41^{\mathrm{D}}$ \\
\hline T5 & $9,95^{\mathrm{B}}$ & $1514,42^{\mathrm{A}}$ \\
\hline T6 & $0,89^{\mathrm{A}}$ & $425,43^{\mathrm{D}}$ \\
\hline $\mathrm{T} 7$ & $0,54^{\mathrm{A}}$ & $531,35 \mathrm{C}^{\mathrm{D}}$ \\
\hline Standard deviation & 0,64 & 259,79 \\
\hline C.V. $(\%)$ & 28,11 & 29,08 \\
\hline
\end{tabular}

$\overline{\mathrm{T} 1}=$ mining floor with one year of planting; $\mathrm{T} 2=$ mining floor with two years of planting; T3 = mining floor with three years of planting; $\mathrm{T} 4=$ tailing with one year of planting; $\mathrm{T} 5=$ woodland soil; $\mathrm{T} 6=$ mining floor without planting; $\mathrm{T} 7=$ tailing without planting. In the area of tailing deposition there was only one planting action. Averages followed by the same letter, in the column, do not differ significantly amongst one another under the Tuckey test at $5 \%$.

Thus, regarding the microbial biomass, it is possible to observe that the planting of the legumes cocktail used for the green manure promoted a significant increase in the BMC, mainly after three years of planting. In relation to the $\mathrm{BMN}$, this planting still has not been long enough to promote alterations in the soil/substract.

\section{Final considerations}

The computational program (SGMAD) developed served the methodological purposes established to select machines and preparation methods in the areas of cassiterite mineral exploitation. However, given the simplicity of its utilization, the user needs a minimum experience in the application of machines and mechanization. This way, its use becomes inseparable from reading this work. The techniques of soil mobilization have proved to be significant to the development of legumes and the recovery of the soil/substract. 
The use of biological indicators in the evaluation of the adopted strategies revealed that the planting of legumes and its later incorporation have been promoting gradual alterations in some of the analyzed soil parameters.

\section{Acknowledgements}

To Fundação de Amparo a Pesquisa do Estado de São Paulo (FAPESP), the BRASCAN and to the Brazilian Institute of the Environment and Mineral Resources you Renewed (IBAMA).

\section{References}

[1] Camargo, O. A. de Alleaoni, L. R. F. Compactação do solo e o desenvolvimento das plantas. Piracicaba: 1997. 132p.

[2] Kepner, R. A., Bainer, R., Barger, E. L. Principles of farm machinery. 3ed. Westport, Avi. 1978. 527p

[3] Leite, Laércio L. et al. Recuperação de Áreas Degradadas, I simpósio SulAmericano e II Simpósio Nacional ., Foz do Iguaçu, 1994. Anais, Curitiba, FUPEF, 679p,1994.

[4] Longo, R.M., Melo, W.J., Ribeiro, A.I., Melo, G.P. Avaliação da biomassa microbiana e atividade da desidrogenase em solo minerado na região amazônica após a introdução da adubação verde. In... Anais Simpósio de Recuperação de áreas degradadas, outurbro de 2006.

[5] Radam Brasil. Folha SC-20. Porto Velho. Rio de Janeiro: Departamento Nacional de Produção Mineral, 1978. 661p. (Levantamento de Recursos Naturais, 16).

[6] Ralisch, Ricardo: Análise comparativa do desempenho de três equipamentos de preparo de solo na descompactação de um Latossolo Roxo, tese de doutorado, UNESP-Botucatu, 1999, 105p

[7] Reis, L.L., Campello, E.F., Franco, A.A. Atividade microbiana de um planosssolo sob plantio de leguminosas arbóreas utilizadas na recuperação de áreas degradadas em comparação ao eucalipto e vegetação espontânea. In: IV Simpósio Nacional de Recuperação de Áreas Degradadas, Blumenau, Anais..., 2000 (Cd room)

[8] Ribeiro, A: I: Avaliação comportamento energético apresentado por três formas geométricas de lâminas de enxada rotativa. Universidade Estadual de Campinas, Dissertação de mestrado. Campinas SP-1997, 67 p.

[9] Sanchez, Luis Enrique. Desengenharia - O Passivo Ambiental na desativação de Empreendimentos Industruiais. São Paulo. Ed. Edusp, 255p. 2001.

[10] Vance, E.D., Brookes, P.C., Jenkinson, A.S. Na extraction method for measuring soil microbial biomass C. Soil Biologic Biochemical, oxford, v.19, p.703-707, 1982. 